\title{
A new omomyid primate from the earliest Eocene of southern England: First phase of microchoerine evolution
}

\author{
Jerry J. Hooker \\ Acta Palaeontologica Polonica 57 (3), 2012: 449-462 doi: http://dx.doi.org/10.4202/app.2011.0017
}

A second species of the microchoerine omomyid genus Melaneremia, M. schrevei sp. nov. is described. It has been collected from the upper shelly clay unit of the Woolwich Formation, earliest Ypresian, Eocene, of Croydon, Greater London, UK. Phylogenetic analysis shows M. schrevei to be the most primitive member of the main clade of the Microchoerinae and demonstrates the initial dental evolution that separated this European subfamily from other omomyids. Calibration of the Woolwich upper shelly clay unit to the later part of the Paleocene-Eocene Thermal Maximum shows that speciation leading to the Microchoerinae took place within $170 \mathrm{ky}$ of the beginning of the Eocene. Tentative identification of $M$. schrevei in the Conglomérat de Meudon of the Paris Basin suggests close time correlation with the upper part of the Woolwich Formation.

Key words: Mammalia, Primates, Melaneremia, evolution, phylogeny, Paleocene-Eocene Thermal Maximum.

Jerry J. Hooker [j.hooker@nhm.ac.uk]. Department of Palaeontology, Natural History Museum, Cromwell Road, London, SW7 5BD, UK.

This is an open-access article distributed under the terms of the Creative Commons Attribution License (for details please see creativecommons.org), which permits unrestricted use, distribution, and reproduction in any medium, provided the original author and source are credited. 